\title{
FOOTBALL PLAYER'S TRAINING FOR IMPROVING PHYSICAL FUNCTION AND HEALTH
}

\author{
TREINO DE JOGADORES DE FUTEBOL AMERICANO PARA A MELHORIA DESUA FUNÇÃO FÍSICA E SAÚDE \\ ENTRENAMIENTO DE JUGADORES DEFÚTBOL AMERICANO PARA LA MEJORÍA DESU FUNCIÓN \\ FÍSICA YSALUD
}

Yong Li ${ }^{1}$ (D)

(Physical Education Professional)

Shanshan $\mathrm{Li}^{2}$ (D)

(Physical Education Professional)

1. China National Football Academy, Shandong Sport University, Shandong Province, China.

2. College of Sports and Health, Shandong Sport University, Shandong Province, China.

\section{Correspondence:}

Shanshan Li

Shandong Province, China. 270102. lishanshan@sdpei.edu.cn

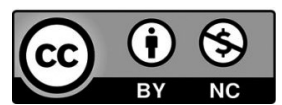

\begin{abstract}
Introduction: Due to the fierce confrontation, high intensity, long duration, and high technical and tactical requirements of modern football, this sport puts forward higher requirements on the physical function of the athletes. Objective: To further explore the importance of physical training based on expounding the concepts of physical fitness and physical training. Methods: The article uses literature research, expert interviews, questionnaires, observations, measurements, mathematical statistics, and other research methods to explore the physical characteristics and training of Chinese football players. Results: The physical training of football players should conform to the specific characteristics of football. This sport requires combining technical and tactical training, psychological training, and academic training of football matches, which must be developed simultaneously. Conclusion: The purpose of physical training is to improve the functional capabilities of athletes to a certain extent, exploit and develop the athlete's athletic potential, and effectively maintain this functional ability. Level of evidence Il; Therapeutic studies - investigation of treatment results.
\end{abstract}

Keywords: Football; Human physical training; Sports; Athletes.

\section{RESUMO}

Introdução: Graças ao confronto físico agressivo, à intensidade elevada, à longa duração, e às exigências técnicas e táticas do futebol americano moderno, esse esporte exige muito da função física de seus atletas. Objetivo: Explorar mais à fundo a importância do treinamento físico baseado na utilização de conceitos de aptidão física e treinamento físico. Métodos: Este artigo utiliza pesquisa bibliográfica, entrevistas com especialistas, questionários, observações, mensurações, estatísticas matemáticas, e outros métodos de pesquisa para explorar as características físicas e o treinamento de jogadores de futebol americano chineses. Resultados: O treinamento físico de jogadores de futebol americano deve estar de acordo com as características específicas do esporte, que requer uma combinação de treino tático, técnico, psicológico e acadêmico, no que diz respeito a partidas de futebol americano, todos os quais devem ser desenvolvidos simultaneamente. Conclusão: O objetivo do treinamento físico é aprimorar a capacidade funcional de atletas até certo ponto, explorar e desenvolver o potencial físico do atleta e, efetivamente, manter sua habilidade funcional. Nível de evidência ll; Estudos terapêuticos - investigação de resultados de tratamento.

Descritores: Futebol Americano; Condicionamento Físico Humano; Esportes; Atletas.

\section{RESUMEN}

Introducción: Gracias al confrontamiento físico agresivo, a la intensidad elevada, a la larga duración, y a las exigencias técnicas y tácticas del futbol americano moderno, este deporte exige mucho de la función física de sus atletas. Objetivo: Explorar más a fondo la importancia del entrenamiento físico basado en la utilización de conceptos de aptitud física y entrenamiento físico. Métodos: Este artículo utiliza investigación bibliográfica, entrevistas con especialistas, cuestionarios, observaciones, mediciones, estadística matemática y otros métodos de investigación para explorar las características físicas y el entrenamiento de jugadores chinos de fútbol americano. Resultados: El entrenamiento físico de jugadores de fútbol americano debe estar de acuerdo con las características específicas del deporte, que requiere una combinación de entrenamiento táctico, técnico, psicológico y académico, con respecto a partidos de futbol americano, que deben desarrollarse simultáneamente. Conclusión: El objetivo del entrenamiento físico es mejorar la capacidad funcional de atletas hasta cierto punto, explorar y desarrollar el potencial físico del atleta y, efectivamente, mantener su habilidad funcional. Nivel de evidencia Il; Estudios terapéuticos - investigación de resultados de tratamiento.

Descriptores: Fútbol Americano; Acondicionamiento Físico Humano; Deportes; Atletas. 


\section{INTRODUCTION}

The special physical fitness of a football player is the functional ability or working ability of the body's various organ systems that the body has to meet the special needs of football. It mainly depends on intrinsic genetic factors and acquired training factors. However, both the selection and the training must be scientifically evaluated. However, for a long time, the research on the evaluation methods and indicators of the effects of football players'special physical training has not attracted enough attention. 'Many vague and even wrong concepts hinder the healthy development of football. This slows the progress of scientific training. Due to the lack of theoretical discussion and methodological research, there are no good methods for athletes'selection and testing of specific functions and evaluating the effects of specific physical training. Therefore, to realize the scientific football training, the research on football-specific physical fitness evaluation methods has become an urgent problem to be solved.

This article takes 70 outstanding football players to research specific physical fitness testing methods. ${ }^{2}$ The reliability and specificity of the method to reflect the specific physical fitness of football players are tested through the test of physiological and biochemical indicators and the analysis of related factors.

\section{METHOD}

\section{Research objects}

We selected 70 outstanding athletes from more than 1,000 athletes who participated in the national men's youth football training camp as the research objects.

\section{Experimental method}

\section{Special physical fitness measurement for sports fields}

We test the athletes in groups. After 20 minutes of warm-up activity, take a short break and run 30 meters repeatedly with full force, with a fixed interval of 50 seconds each time. The blood lactate was measured immediately after the 12 th run. Then continue to run for $30 \mathrm{~m}$ repeatedly until tired. ${ }^{3}$ Suppose the speed drops significantly or the subjective feeling is unwilling to continue exercising more than 2 times in a row. In that case, it is a symptom of exercise fatigue, and the exercise is terminated. Record the time of each $30 \mathrm{~m}$ run and the total number of repeated runs (n). Calculate the maximum speed ( $\operatorname{Vmax}$ ) and average speed (CP-re). Calculate the Specific Fitness Index (FFI) based on the total number of times/average time. We tested blood lactic acid (HL1, HL2) after the 12th run and after exercise to fatigue, CK enzyme, blood urea nitrogen (BUN), hemoglobin, and other indicators immediately after exercise and the next morning.

\section{Laboratory determination of cardiopulmonary function and aerobic capacity}

We measured the aerobic capacity of 20 athletes in the laboratory using MAX-exercise cardiorespiratory made in the United States. Perform adaptive exercises on the treadmill for 5 minutes before the test. ${ }^{4}$ Volunteers exercise on the active treadmill according to the set Bruce incremental load running program. Start load $2.7 \mathrm{~km} / \mathrm{h}$ and increase the load to exercise until it can't continue. Exhaled breath during exercise enters the gas analyzer through the connected collection device for automatic analysis, real-time display, and recording, and more than 20 parameters such as oxygen consumption, ventilation, and oxygen pulse are tested.

All data were statistically processed on the PC using SPSS11.0 statistical software package and EXCEL2000 loading statistical software package. The significance level is $\mathrm{P}<0.05 \sim, \mathrm{P}<0.001$.

\section{Description of fitness test problem}

Suppose there are $m$ physical fitness test items. There are $n_{i}(i=1$, $2, \cdots, m)$ sets of electronic equipment for the physical fitness test in item $i(i=1,2, \cdots, m)$. At most $k_{i}(i=1,2, \cdots, m)$ people can test at the same time for one instrument at a time. Existing individual $N$ will perform the physical fitness test. ${ }^{5}$ The time $d_{i j}(i=1,2, \cdots, m ; j=1,2, \cdots, N)$ required for each person to complete the $i(i=1,2, \cdots, m)$ test item.

The vertex set $V=\{1,2, \cdots, m\}$ represents the physical fitness test item. Each vertex $i$ has $n_{i}(i=1,2, \cdots, m)$ sub-vertices. Each sub-vertex can be included in $k_{i}(i=1,2, \cdots, m)$ paths at the same time. There are $m(m-1) N$ arcs in the arc set $A$. The weight on each arc represents the time $d_{i j}(i=1,2, \cdots, m ; j=1,2, \cdots, N)$ required for the $j$ person to do the end item $i$. There is no arc between the sub-vertices. ${ }^{6}$ The problem requires $N$ loops including $m$ sub-vertices, and we minimize the sum of weights of each loop. We represent the TSP problem as a complete graph. The vertex represents the city. Suppose the number of ants in the ant colony is $M . d_{i j}(i, j=$ $1,2, \mathrm{~L}, n)$ represents the length of the path between vertices $i$ and $j$. Assuming that $B_{i}(t)$ represents the number of ants at the vertex F at the time $t$, then $M=\sum B_{i}(t), \tau_{i j}(t)$ represents the amount of information remaining on the arc $(i, j)$ at a time $t$. The initial time $\tau_{i j}(0)=C(C$ is a constant, usually taken as 0$)$. Ant $k(k=1,2, \cdots$, $M$ ) determines the transfer direction according to the amount of information on each path during the movement. ${ }^{7}$ At the time $t$, the probability of ant $k$ transferring from vertex $i$ to $j$ is

$p_{i j}^{k}(t)=\left\{\begin{array}{cc|}\frac{\left[\tau_{i j}(t)\right]^{a}\left[\eta_{i j}\right]^{\beta}}{\sum\left[\tau_{i j}(t)\right]^{{ }^{2}\left[\eta_{i j}\right]^{\beta}}} & j \in \text { allowed }_{k} \\ 0 & j \notin \text { allowed }_{k}\end{array}\right.$

$\eta_{i j}$ represents the desired degree of transition from vertex $i$ to vertex $j$. When $\eta_{i j}>0$, the probability that the ant in the neighborhood $i$ will move to the neighborhood $j$ according to the probability $p_{i j}$. When $\eta_{i j}>0$, the ants in the neighborhood $i$ do a neighborhood search. $a$, $\beta$ respectively represents the information and heuristic factors accumulated by the ants during the movement. After $\Delta t$ period the ants complete a cycle. ${ }^{8}$ The formula for refreshing the amount of pheromone on each arc $(i, j)$ is

$\tau_{i j}(t+\Delta t)=\rho \tau_{i j}(t)+\Delta \tau_{i j}(\Delta t)$

$$
\Delta \tau_{i j}(\Delta t)=\sum_{k=1}^{m} \Delta \tau_{i j}(\Delta t)
$$

$\Delta \tau^{k}{ }_{i j}$ respectively represents the amount of pheromone left by all $m$ ants and the $k$ ant on $\operatorname{arc}(i, j)$ in this cycle $\Delta t$ time. The calculation formula of $\Delta \tau_{i j}^{k}$ is

$$
\Delta \tau_{i j}^{k}=\left\{\begin{array}{cc}
R / L_{k} & k \in(i, j) \\
0 & k \notin(i, j)
\end{array}\right.
$$

In the formula, $R$ is a constant. $L_{k}$ represents the length of the road traveled by the $k$ ant in this cycle. That is $L_{k}=\sum d_{i j}$. The parameter $R$, $C \alpha, \beta, \rho$ appearing in the above formulas can be tested to determine its optimal combination. The expression form of $\tau_{i j}(t), \tau_{i j}(t+\Delta t)$ and $p_{i j}^{k}(t)$ can be determined according to the specific problem. 


\section{RESULTS}

Table 1 and Table 2 show the test results of various indexes of football players in repeated $30 \mathrm{~m}$ runs. It can be seen from Table 1 that the average value of $\mathrm{HL} 1$ is about $7.12 \mathrm{mmol} / \mathrm{L}$, and the average value of $\mathrm{HL} 2$ is $8.56 \mathrm{mmol} / \mathrm{L}$. This is similar to the results reported in a football match's on-the-spot test of the lactic acid value. When the specific physical fitness index is between 6 and 12, the $\mathrm{HL}$ is between 9.15 and $9.44 \mathrm{mmol} / \mathrm{L}$. This shows that the increase in the specific physical fitness index is not closely related to the glycolytic energy supply capacity. (Table 2) Even after exercising to fatigue, the blood lactic acid concentration has not reached the highest value, equivalent to the measured value of $100 \mathrm{~m}$ runners. This shows that energy is mainly provided by the ATP-CP system and aerobic energy supply system during exercise.

The relationship between football-specific physical fitness and aerobic capacity is shown in Table 3 and Table 4. We use the fitness index FFI to represent the comprehensive index of football-specific physical fitness and the index determined by the laboratory aerobic capacity to test the correlation. In this way, it is possible to determine the role and status of specific physical fitness to reflect the athlete's specific aerobic capacity. The results show that football players'specific physical fitness index (FFI) is very significantly correlated with the relative maximum aerobic capacity $\mathrm{VO}_{2} \mathrm{max} / \mathrm{kg}$, AT $\left(\mathrm{VO}_{2} \mathrm{max} \%\right), \mathrm{VEQO}_{2}$, and other indicators ( $\mathrm{P}<0.01$, Table 3 and Table 4). This shows that the special physical fitness test method and physical fitness index can better reflect the aerobic metabolism of athletes.

The test results showed that the male football player's specific physical fitness index averaged 6.15. According to the correlation between physical fitness index and physiological indicators, we divide the physical fitness index of football players into three levels: excellent, good, and pass. (Table 5)

Table 1. A list of the various indicators of the tested football players in the 30-meter repeated run.

\begin{tabular}{c|c|c}
\hline & Average & standard \\
\hline Vmax $(\mathrm{m} / \mathrm{s})$ & 7.09 & 0.29 \\
\hline $\mathrm{n}$ & 28.31 & 7.07 \\
\hline $\mathrm{V} / 12(\mathrm{~s})$ & 6.726 & 0.33 \\
\hline $\mathrm{CP}-\mathrm{re}$ & 6.667 & 1.1 \\
\hline $\mathrm{FFI}(\mathrm{N} / \mathrm{N})$ & 6.15 & 1.93 \\
\hline $\mathrm{HRmax}(\mathrm{n} / \mathrm{min})$ & 168.54 & 10.27 \\
\hline $\mathrm{HL} 1(\mathrm{mmol} / \mathrm{L})$ & 7.12 & 2.17 \\
\hline $\mathrm{HL2}(\mathrm{mmol} / \mathrm{L})$ & 8.56 & 2.37 \\
\hline
\end{tabular}

Table 2. A list of biochemical indicators of the football players tested in this study after a repeated $30 \mathrm{~m}$ run.

\begin{tabular}{c|c|c}
\hline & Average & Standard deviation \\
\hline $\mathrm{CK} 1(\mathrm{u} / \mathrm{L})$ & 341.54 & 149.58 \\
\hline $\mathrm{CK} 2(\mathrm{u} / \mathrm{L})$ & 430.47 & 104.11 \\
\hline $\mathrm{Hb}(\mathrm{g} / \mathrm{L})$ & 153.54 & 9.78 \\
\hline $\mathrm{BUN}(\mathrm{mmol} / \mathrm{L})$ & 5.34 & 0.97 \\
\hline $\mathrm{URO1}(\mathrm{mg} / \mathrm{dl})$ & 1 & 0 \\
\hline $\mathrm{PH} 1$ & 6.14 & 0.64 \\
\hline $\mathrm{PH} 2$ & 6.01 & 0.42 \\
\hline $\mathrm{SG} 1$ & 1.02 & 0.01 \\
\hline $\mathrm{SG} 2$ & 1.03 & 0.01 \\
\hline
\end{tabular}

Table 3. The test results of the correlation between the specific physical fitness index and the physiological indicators of aerobic capacity of the tested football players in this study.

\begin{tabular}{c|c|c|c|c|c|c|c}
\hline & $\mathbf{V O}_{\mathbf{2}} / \mathbf{K G}$ & $\mathbf{V O}_{2} \mathbf{m a x}$ & $\mathbf{O}_{2}$ pulse & VE & AT & HRmax & $\mathbf{E Q O}_{2}$ \\
\hline \multirow{2}{*}{ R value } & 0.615 & 0.471 & 0.863 & 0.477 & 0.546 & -0.485 & 0.594 \\
\cline { 2 - 8 } & 0.032 & 0.012 & 0.014 & 0.002 & 0.031 & 0.002 & 0.011 \\
\hline P value & $<0.01$ & $<0.01$ & $<0.001$ & $<0.01$ & $<0.01$ & $<0.01$ & $<0.01$ \\
\hline
\end{tabular}

Table 4. Correspondence list of physiological indicators in this study and the regression equation of the special fitness index.

\begin{tabular}{c|c|c|c|c|c|c}
\hline Specific fitness index level & $\mathbf{2}$ & $\mathbf{4}$ & $\mathbf{6}$ & $\mathbf{8}$ & $\mathbf{1 0}$ & $\mathbf{1 2}$ \\
\hline $\begin{array}{c}\text { Regression equation to } \\
\text { calculate CK1 value }\end{array}$ & 309 & 321 & 333 & 345 & 357 & 369 \\
\hline $\begin{array}{c}\text { Regression equation to } \\
\text { calculate CK2 value }\end{array}$ & 363 & 412 & 461 & 509 & 558 & 607 \\
\hline $\begin{array}{c}\text { Regression equation to } \\
\text { calculate Hb value }\end{array}$ & 146.5 & 149.8 & 153.1 & 156.4 & 159.7 & 163 \\
\hline $\begin{array}{c}\text { Regression equation to } \\
\text { calculate BUN value }\end{array}$ & 5.717 & 5.539 & 5.56 & 5.181 & 5.002 & 4.824 \\
\hline $\begin{array}{c}\text { Regression equation to } \\
\text { calculate HL2 value }\end{array}$ & 8.96 & 9.057 & 9.153 & 9.249 & 9.346 & 9.442 \\
\hline
\end{tabular}

Table 5. A list of the distribution of the specific physical fitness index of the tested football players in the 30-meter repeated run.

\begin{tabular}{c|c|c|c}
\hline & Pass & Good & Excellent \\
\hline Special index range & $3.2 \sim 4.5$ & $4.5 \sim 5.9$ & 6.0 or above \\
\hline People who reached the index (n) & 11 & 20 & 39 \\
\hline $\begin{array}{c}\text { Percentage of total } \\
\text { number of people (\%) }\end{array}$ & 15.7 & 28.6 & 55.7 \\
\hline
\end{tabular}

\section{DISCUSSION}

The ability of the aerobic metabolic system to quickly restore the high-energy phosphate system in a football game is the remarkable aerobic capacity of football. This is the main ability that constitutes a football player's specific physical fitness, and it is also the core of the football player's specific physical fitness training. Special physical fitness tests for football players must reflect this ability. Experiments show that the test method is simple, repeatable, and highly maneuverable. We can test directly on the sports field.

The specific physical fitness of football players includes specific aerobic capacity and specific anaerobic capacity. Aerobic energy supply provides most of the energy in repeated sprint exercises. And the more sprints, the more important aerobic energy metabolism. Therefore, the total number of repeated runs of 30 meters can mainly reflect the specific aerobic capacity.

The average values of CK enzyme immediately after exercise and the next morning after exercise were $341.54 \mathrm{u} / \mathrm{L}$ and $430.47 \mathrm{u} / \mathrm{L}$, respectively. The athletes' CK value increased by $53 \%$ the next morning. The average blood urea the next morning was $5.35 \mathrm{mmol} / \mathrm{L}$, which was within the normal range. This shows that this kind of exercise load method is very strong. Its impact on the body is profound. We will continue to observe athletes whose CK enzyme value exceeds 600u/L the next morning for more than 24 hours. From the result analysis, the overall sample mean of the CK value is still within the normal range. This shows that the overall load is within the normal range and that the method is safe and reliable.

The average physical fitness index of male football players is 6.15 , between 3.2 and 10.6. According to the correlation between physical fitness index and physiological indicators, the physical fitness index of football players is divided into four levels: excellent, good, passing, and failing. Because it is mainly based on empirical observation and cannot seek objective quantitative standards, there are also a small number of athletes whose physical fitness index only reaches the passing level or even the failing level. If enrolled following the exceptional physical fitness test standards before the selection, the misselection rate can be reduced by $15.8 \%$.

\section{CONCLUSION}

We use a fixed interval time of $30 \mathrm{~m}$ repeated full-load running load method to test the specific physical fitness of football players. The method is simple, reliable, and highly maneuverable. We compare it with other physical fitness testing methods and indicators to better reflect football players'specific physical fitness levels.

All authors declare no potential conflict of interest related to this article 


\section{REFERENCES}

1. Kostiukevych VM. Model indicators of collective interactions of highly qualified football players during the game. Health, sport, rehabilitation. 2019;5(4):33-40.

2. Bjelica D, Gardasevic J, Vasiljevic I, Masanovic B. Changes in the morphological characteristics and body composition of elite montenegrin football players during the competition period. Journal of Anthropology of Sport and Physical Education. 2020;4(3):15-18.

3. Milanović Z, Pantelić S, Čović N, Sporiš G, Mohr M, Krustrup P. Broad-spectrum physical fitness benefits of recreational football: a systematic review and meta-analysis. British journal of sports medicine. 2019:53(15):926-39

4. Sangnier S, Cotte T, Brachet O, Coquart J, Tourny C. Planning Training Workload in Football Using Small-Sided Games' Density. The Journal of Strength \& Conditioning Research. 2019;33(10):2801-11.
5. Ibrahim AR, Na'amhassan M. The Predictive Value of Describing the Physical Condition in Terms of the Personal Struggle among the Players of the Directorates of Physical Training and Police Games in the Football Game. Annals of the Romanian Society for Cell Biology. 2021;25(6):15133-41.

6. Kittel A, Elsworthy N, Spittle M. Incorporating perceptual decision-making training into high-intensity interval training for Australian football umpires. Journal of sports sciences. 2019;37(1):29-35.

7. Zavalishina SY, Makurina ON, Mal GS, Tkacheva E. Influence of Systematic Football Training on Adolescent Functional Characteristics. Biomedical and Pharmacology Journal. 2021;14(2):533-40.

8. Abdullaeva BP. Teaching a Child to Play Football From A Youth. The American Journal of Interdisciplinary Innovations Research. 2021;3(4):147-51 